\title{
PORTABLE TELEMATIC SYSTEM AS AN EFFECTIVE TRAFFIC FLOW MANAGEMENT IN WORKZONES
}

\author{
Marek Š̌̌erba ${ }^{1}$, Tomáš Apeltauer ${ }^{2}$, Jiři Apeltauer ${ }^{3}$ \\ ${ }^{1}$ Centrum dopravního výzkumu \\ Brno, Czech Republic \\ Lišeňská 33 a the present address \\ Phone: +420 606689956, e-mail: marek.scerba@cdv.cz \\ ${ }^{2}$ Brno University of Technology, Faculty of Civil Engineering \\ Brno, Czech Republic, Veveři 331/95 \\ Phone: +420 737383 389, e-mail: apeltauer.t@fce.vutbr.cz \\ ${ }^{3}$ Brno University of Technology, Faculty of Civil Engineering \\ Brno, Czech Republic, Veveři 331/95 \\ Phone: +420 541147 356,e-mail: apeltauer.j@fce.vutbr.cz
}

\begin{abstract}
Traffic infrastructure localities with temporal restrictions for example due to reconstructions, or modernization, are important aspects influencing the traffic safety and traffic flow. On the basis of our research, we can identify main factors, which generate travel time loses, and which often cause traffic accidents in bottlenecks. First of all, it is improper late merge, speeding, tailgating, lower tolerance and consideration to other road users. Nervousness and ignorance of drivers also play an important role in generation of traffic congestions, lower level of service and resulting external economic loses. One of the tools eliminating the traffic restriction negative impacts is usage of portable telematics systems. In 2011 to 2013,project ViaZONE was in progress, which was to design an intelligent system with the aim to eliminate the mentioned risks and reduce economic losses generated by traffic congestions. Using available data and information, we have proved profitability and cost-effectiveness of dynamic systems for traffic control of work zones. Regarding traffic management, the system showed some problems due to indisciplined drivers and the system proved that speeding in these hazardous road segments is a common practice which caused accidents and congestions
\end{abstract}

Keywords: Workzones, Traffic management, accident, congestion, detectors, portable variable message signs

\section{Introduction}

The reconstruction and modernization of highways is a complicated process in all countries while developing road infrastructure. Unlike smaller roads, highways and major roads do not usually have a comparable alternative, which could be used by the drivers in the course of reconstruction. As a consequence, work is usually done during normal traffic, which inevitably leads to formation of bottlenecks. In such case it is necessary to try finding an effective, but also affordable way of managing the traffic flow in the working zone and the surrounding areas in order to minimize the negative effects on road capacity, and safety of not just the drivers, but also the workers themselves. In 2011 to 2013, project ViaZONE was in progress "Traffic Flow Harmonisation and Increase of Road Capacity at Road Works with the Use of Co-operating ITS Systems - Portable Traffic management", which was to design an intelligent system with the aim to eliminate the mentioned risks and reduce economic losses generated by traffic congestions.

The research team consisted of Centrum dopravního výzkumu, v.v.i. as the coordinator and cooperating organizations HIT HOFMAN, s.r.o. and Brno University of Technology, Faculty of Civil Engineering. The project was funded by Technological Agency of the Czech Republic within Alfa programme. The project aimed to develop, produce, test and verify a pilot operation of "Portable System of Traffic Management", particularly on sites in front of and in traffic closures. The aim of the project was reached in December 2013, when the pilot operation of the system was finished on a motorway D1 segment between Brno and Vyškov.

This paper presents the result of the impact assessment of the pilot testing VIAZONE system.

Some political issues of research which were done in frame of POLITE project funded under INTERREG IVC programme of European Union have been introduced in this paper as well. 


\subsection{The portable telematics system - ViaZONE}

The system in question consists of interoperable components, which are tailor-made to the requirements for portable systems [6]. The main feature of these components is their modularity, portability, minimum requirements for installation, calibration and maintenance, economic operation, and independence of mains. The complex system is a set of HW and SW tools which allow for an effect on drivers through portable, mobile, variable road signs. Unique algorithms for the displayed pictograms and messages on variable road signs are displayed in real time on the basis of evaluated input data from various traffic detectors which are installed in several predefined profiles of an area in question. Reliability of all used components of the system was verified during testing. Evaluating and control software allowed for remote controlling and automated operation of the system without any problems. Subsequently, the data from the measuring and system operation were evaluated and methodology "Methods to Improve Road Safety and Traffic Flow at Traffic Closures Using ITS” was produced.

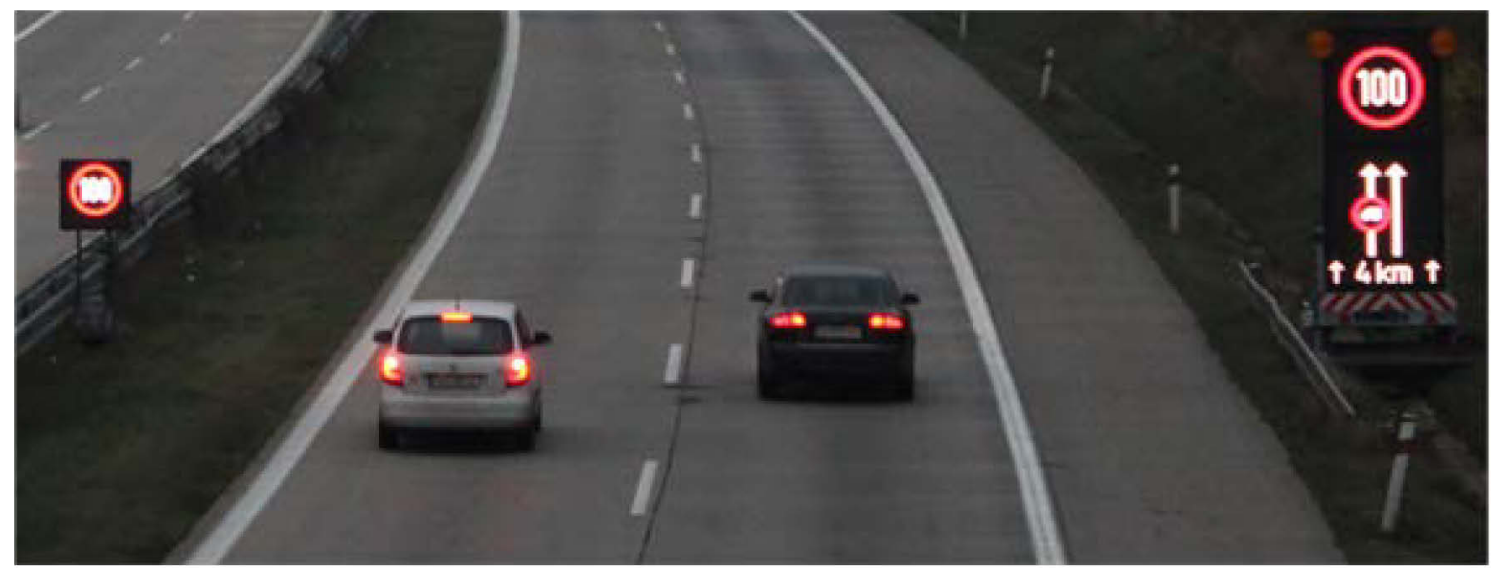

Figure 1. Illustrative photo made during system pilot testing

\section{Theoretical background for system effectiveness}

In-depth analysis of traffic flow behaviour at road closures was performed in the first stages of the project. Traffic detectors were installed at several reference traffic closures for the period of 6 weeks. The obtained data were used for creation of micro-simulation models. Input values of the model were obtained from measurements performed on highway closures and also using the values for estimating the capacity of highway closures in [1] and [2]. Traffic flow model was calibrated and validated in comparison with the source data from floating vehicles [8]. Control scenarios, which were verified on the models, were created in the other stage. After performing more than 300 simulation tests, the most suitable scenario was selected (Graph 1 shows Scenario 2), which was a combination of adaptable speed reduction and warning system with the function of informing of queues, possibly other hazards. The system design and algorithms used in model has been suggested in relationship between capacity and driver behaviour [3].

The performed analyses show that the use of dynamic controlling according to Scenario 2 is able improve the capacity of a bottleneck by approximately $10-15 \%$.

Regarding the late merge, the critical value for the Czech Republic is approximately $1400 \mathrm{v} / \mathrm{h}$. Higher traffic volume is beyond the capacity of late merge and queues are likely to occur. Model cases show that the use of the dynamic system may lead to the harmonization of traffic flow and the rule of late merge could be respected more (with the current vehicles classes). Regarding traffic closures which uses two narrowed traffic lanes, there is not such frequent occurrence of queues, but queues and significant time losses are likely in crisis situations and peak hours.

The conclusion of analytical studies show that dynamic controlling in work zones may lead to significant road safety improvement and improvement of travel times by $10 \%-15 \%$ and reduction of the number of vehicles standing in the queue by $15 \%-20 \%$. 


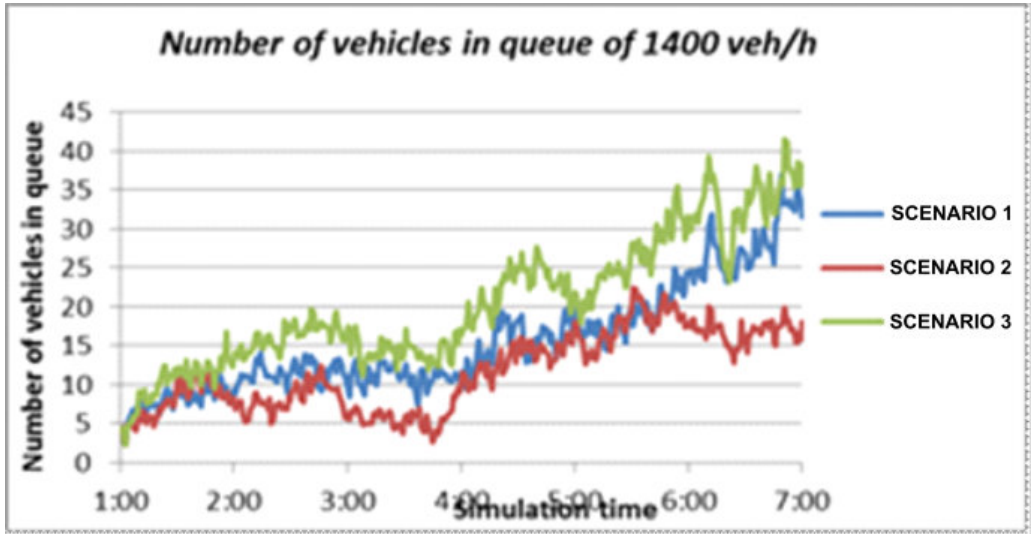

Graph 1. Number of vehicles in queue of $1400 \mathrm{veh} / \mathrm{h}$

\section{Pilot testing of an innovative system}

\subsection{Basic information on road closure}

Reconstruction of motorway D1 near Brno started in the middle of 2013. This concrete road pavement reconstruction was the largest reconstruction of D1 with the exception of the modernized segments between Brno and Prague which are under the progress. The traffic was guided in both directions in two auxiliary traffic lanes using the hard shoulder.

In the time period from 20 September 2013 to 3 December 2013, a system of Portable traffic management, which is the main outcome of the project of Portable Traffic Management, was installed on motorway segment Olomouc - Brno on kilometres 213 to 229.

\subsection{System architecture within pilot testing}

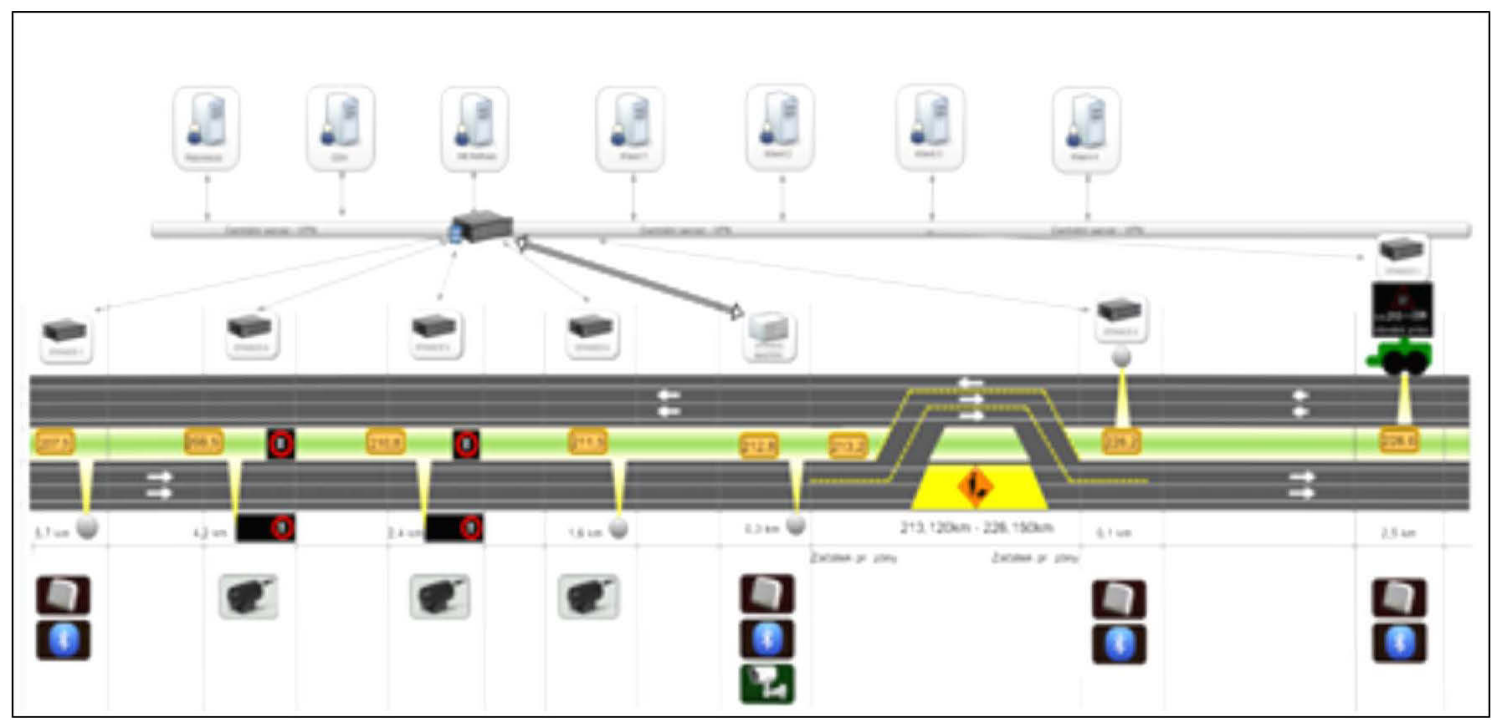

Figure 2. Complete architecture within pilot testing on D1 motorway segment between kilometers of $207.5-229.5$ in [4]:

During the pilot testing has been installed these system components with respect of requirements

- $\quad$ Portable VMS installed in the middle of the road $(2 x)$

- Information trailer LED (3x)

- Nonintrusive traffic detector Wavetronix $(4 \mathrm{x})$

- The queue radar detectors $(3 \mathrm{x})$

- Travel time detectors (4x bluetooth detectors)

- Camera 
- Industrial PC with minimum power consumption, compatible with all detection and display components with GPS, GPRS (9x)

- Evaluation software

- Alternative source of energy

The evaluation software has been installed in the station MASTER $(212.650 \mathrm{~km})$ as well as in the central server. It concerns redundancy evaluation, while the basic evaluation is performed in the central server. The supervisory and controlling software ViaZONE was installed on the motorway Police department and Highway directorate of Czech Republic and on the organization which provided the servicing and maintenance of the system. Regarding alarm situations (technology failures, critical power supply status of batteries, etc.), the system informed operators and send text messages to selected phone numbers with such message content which specifies he identified problem. This function aims to speed up a reaction to the occurred problem. All system functions respected the requirements in [5].

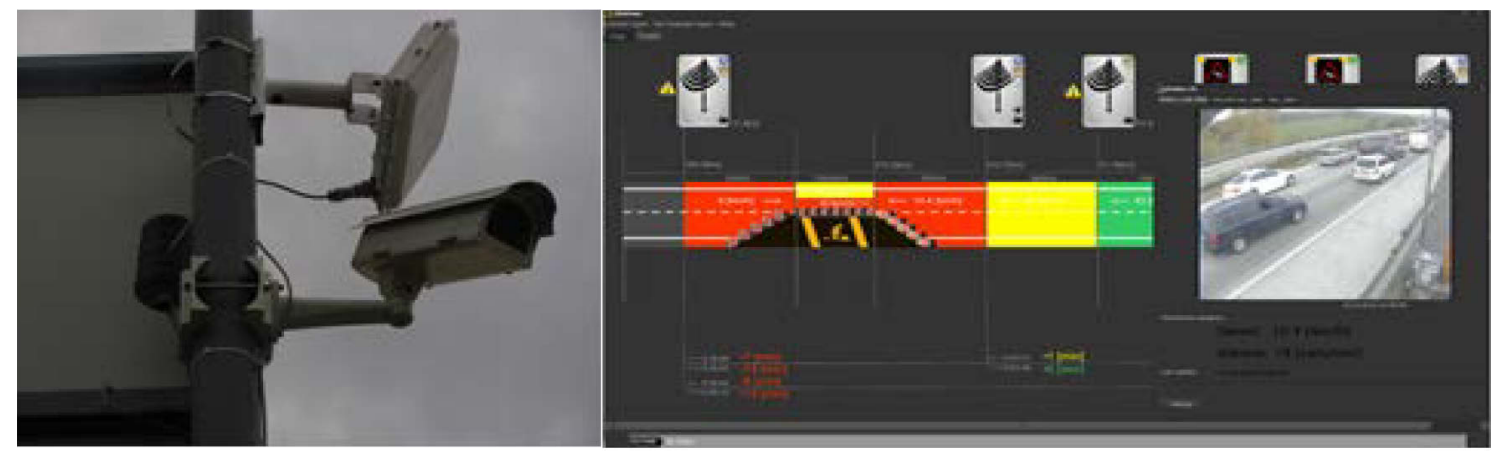

Figure 3. Portable detectors on the left and printscreen from the on-line visual control SW on the right

\section{Evaluation of the pilot testing}

Testing of the system can be divided into four separate chapters.

- Analysis of accidents

- Analysis of economic indicators

- Technical matters

- Traffic management

\subsection{Analysis of accidents}

During the period of traffic closures in 2013 (71 days), 48\% (25 accidents) of all accidents in that year were reported on the monitored segment. We are talking about incidents where the Police of the CR had to intervene. In 2012, traffic closures on the same segment lasted only 53 days, however, during that period occurred 17 accidents, which is $33 \%$ of all accidents in that particular road segment in 2012.

For example during the 71 days immediately prior to installation of traffic closures only one traffic accident occurred on this segment of the motorway. In the period from January to June 2013 there were 26 accidents in the monitored segment. So in the test segment, during the two years of monitoring there was 3.84 times higher probability of an accident in the segment with transport limitations compared to the period with no traffic limitations on the monitored segment. From these data it is evident that road closures are significant risky places, which should be provided with a system to harmonize traffic, in combination with repressive systems that will enhance respect for road signing and marking.

\subsection{Analysis of economic losses due to the work zone on D1 and congestions at the site of pilot installation}

After completion of the testing it was attempted to determine the total economic losses incurred due to delays in the work zone near Vyškov and show the importance of measures that lead to elimination of delays and traffic accidents. For these calculations, we used data from the system RODOS (from the system of floating car data) [8], where we compared the five-minute aggregated outputs from ASIM detectors located at road mileage 207 and 226 (traffic volume, classification) with the values of delay in 
individual segments of the affected site. As input values for idle time of cars, trucks and buses we used the HDM-4 methodology [7]. All 71 days of the existence of this work zone were covered and all delays in the segments exceeding 3 minutes were included.

Table 1. Total time losses due to the traffic closure, quantified in Czech crowns

\begin{tabular}{|l|l|l|l|}
\hline Total losses & Cars & Trucks & Total losses \\
\hline $\begin{array}{l}\text { Direction Vyškov - } \\
\text { Brno }\end{array}$ & CZK 53,378,380 & CZK 26,687,742 & CZK 80,066,132 \\
\hline $\begin{array}{l}\text { Direction Brno - } \\
\text { Vyškov }\end{array}$ & CZK 9,147,871 & CZK 4,768,595 & CZK 13,916,466 \\
\hline
\end{tabular}

\subsection{Technical matters}

The testing of the system was technically successful. The assumption of system reliability proved true and testing also revealed weaknesses of the system that were tuned in the process of testing. Of course, even after testing the system continues to be enhanced. From this perspective, testing of the system under practical conditions is irreplaceable. Laboratory conditions and theoretical assumptions can never discover specific cases that arise only in real-world conditions. On the technical side we note in particular the following results of the pilot testing:

- We have verified the reliability of bluetooth detection and benefits for control algorithms of the system. The hypothesis proved true that $10 \%$ penetration rate of equipped vehicles is sufficient as an input for dynamic traffic management and at the same time, such a penetration rate occurs on the roads in the Czech Republic at any time of the day.

- We have attested the accuracy of detectors, which can be used as an alternative to stationary detection devices with the accuracy more than $95 \%$ in intensity and more than $85 \%$ in classification

- Configuration and control SW was significantly changed during the testing and after. We have attested the feasibility of traffic management on the basis of matrix algorithms that allow easy adjustment of algorithms by a normal system user. In this context it should be noted that during the testing, control algorithms have evolved considerably, especially with regard to crisis management, such as when the required data from any of the detection profiles are not available.

- We have verified the reliability of evaluation HW system elements that can be without any problems powered by batteries or solar cells.

- It was verified (5) that the system cannot operate on only one communication technology. GPRS technology is not sufficiently permeable to allow (at least in $99 \%$ of cases) sending the data every minute to the evaluation server. This interval was defined as the minimum necessary for traffic management.

- Control SW Viazone, or more precisely the control algorithms of the system allowed commanding the Information trailer LED from different supplier, which demonstrated the possibility of independence of the system on LED technology vendors.

- The possibility of trouble-free maintenance of interim ITS systems was demonstrated what is suggested in (4). Regular replacement of batteries in the central reserve may be routine and very fast operation that does not disturb traffic flow.

\subsection{Traffic management matters}

If we wanted to fulfil the theoretical assumptions drawn from the prepared calibrated models and shorten travel times and the length of queues in the place of work zones with the use of dynamic management (theoretical models indicate the potential for improved traffic-carrying capacity by more than $10 \%$ ) based on the speed limit, it would be necessary to propose additional measures. The degree of acceptance of variable road signs by drivers is insufficient and disobedience and arrogance of most drivers occurs. The data showed that traffic flow is faster on average by about $20 \mathrm{~km} / \mathrm{h}$ than is the permitted speed limit, even at places of work zones where workers are moving and the width of lanes is significantly reduced.

An average traffic volume was 27 vehicles/ min (minimum of 10 vehicles/min, maximum 45 vehicles/min). The speed was evaluated for 5 minutes. From the performed tests we can conclude that by displaying the road sign 80 , slowing the speed of traffic flow by about $25 \%$ down to the speed of around $100 \mathrm{~km} / \mathrm{h}$ (at best) is achieved. Better results is obtained by displaying a warning sign "Queue" 
(results are better than with maximum 80). The average speed was reduced to the speed around $95 \mathrm{~km} / \mathrm{h}$. Before displaying the symbol, the speed of traffic flow was $112 \mathrm{~km} / \mathrm{h}$ (max. $115 \mathrm{~km} / \mathrm{h}$ and $\min .108 \mathrm{~km} / \mathrm{h}$ ). In the first minute, traffic flow moved without limitation, in minute 2-3 there was also no significant decrease in the speed (average $107 \mathrm{~km} / \mathrm{h}$ ) but in the 4th minute the average was $92.4 \mathrm{~km} / \mathrm{h}$ and in the 5 th minute $98.2 \mathrm{~km} / \mathrm{h}$.

From the above it can be deduced that drivers react more to warning road signs that symbolize certain approaching danger than to speed limit signs.

These results, however, are insufficient for traffic management, as they do not match the model assumptions by far and therefore it is not possible to make a reliable statement on the effectiveness of the tested pilot system to improve traffic flow and increase throughput at bottlenecks. It is also not possible to make a credible statement with regard to the length of pilot installation, since the effectiveness and efficiency of the system should be evaluated at least after 1-2 years of its routine operation.

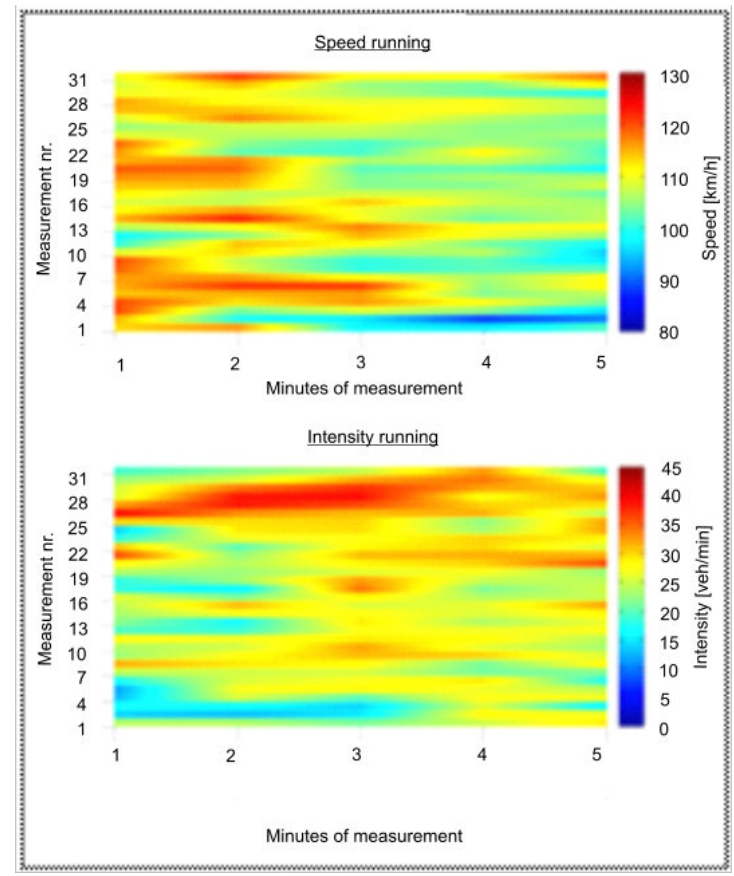

Diagram 1: Comparison of speeds and traffic volumes during the long-term measurement There is no apparent relationship between speed limit compliance and traffic volume. Upper diagram show the slowing traffic flow, if the $\max 80 \mathrm{~km} / \mathrm{h}$ has been displayed

\section{Telematics system's economic indicators}

In order to estimate the benefits of active management of work zones it is not possible to make a simple statement that traffic flow improved and travel times shortened. The initial investments in the system and its subsequent operation generate substantial costs that need to be taken into account. When calculating the economic indicators of the system a model case was established, which was simulated based on real data. The simulation was carried out on a calibrated traffic model that was created in earlier stages of the project and related to one traffic closure in each direction. Consideration was given to the data that emerged from real testing the system, so the already calibrated models were set according to specific values coming from drivers' reaction to the system (these results are presented later in this document). Therefore, the input values are more realistic compared to initial simulations. Therefore, the creation of an economic model counted with savings in travel times between $7-9 \%$. In the model, the system was used in configuration of an adaptable speed decreasing system of 3 VMS profiles (on both right and left side) and one information trailer. On the other side of the working zone a warning and information system was used in configuration with 2 VMS profiles (both on the right and left side) and an information trailer.

These inputs to the economic model were used:

- Values of time spent in congestions specified by HDM-4 (National methodology) [7] 
- The value of time spent in congestions related to classification of vehicles on the motorway D1 according to data from a fixedly mounted profile detector

- The value of travel time savings during a simulation experiment

- The investment costs of the system.

- Maintenance and operation of the system, including depreciation

- Comparison of benefits and costs of the system

The findings of this economic model show that for the given test configuration and time, the system efficiency index calculated as the ratio of benefits and costs of its operation was CIES $=6.6$. Thus, the system during the monitored time within the simulation period proved to theoretically generate savings of more than six times the operating costs. Index like this is quite crucial for evaluating the economic efficiency of the system.

However, it is important to emphasize that it is not possible to search for a fixed number for the system, but always a combination of the system, installation location and operating time.

The resulting system efficiency index is determined inter alia, by the following factors:

- Traffic volume in the site of installation influences the efficiency index the most. As it turned out, shortening of travel times is in the case of active traffic management more pronounced for low traffic flow, i.e. more vehicles in a queue.

On the contrary, the management may be counterproductive in case of a lower number of vehicles.

- Operating time of the system includes phases during the day with higher and lower volumes, which reflects in its effectiveness. If the system is in operation 24 hours a day, its effectiveness will be lower than in the case where it is active only during the weekdays and only during the daytime.

- Seasons influence drivers' behaviour in work zones. In the winter months, drivers tend to drive more slowly and the dynamics of traffic flow is therefore different from the summer months.

Generally it can be stated that although the system under study was tested on data especially during the time of the day that involves afternoon rush hours, its index is so high that it would fall to the zone of unprofitability only in case of very unfavourable combination of several of these factors acting simultaneously

\section{Conclusions}

All the above facts have one clear and easily verifiable result. In areas of road closures, the probability of traffic accidents is approximately 4 times higher than on the segments of motorways and expressways with no limitations. It is the result of exceeding speed limits, not maintaining safe distances and not adjusting the driving to road surface conditions. However, drivers themselves do not perceive this fact.

From the perspective of research, we can therefore consider the results of this testing as very valuable. In order to achieve the theoretical assumptions of the possibility to reduce economic losses from increased travel times and accidents through telematics tools, it is necessary to seek other appropriate measures. It could be effective to use restrictive measures in the form of heavy fines and point penalties for violations of traffic rules in work zones. It is necessary to take into account the safety of workers in work zones, which is considerably endangered by fast driving. The above mentioned large number of traffic accidents is a sad evidence of the critical situation in complying with traffic rules in work zones.

According to discussions with members of the police force is not easy to penalize drivers in road closures. There is a problem with a place to stop vehicles. For this reason, possibilities should be considered of dedicating a place in road closures to measure the speed of vehicles with the possibility of their stopping. In the long run, it is necessary to increase respect of drivers from these places similarly as in tunnels where exceeding the speed limits is much less frequent.

Another result of the performed tests and analyses shows that the design and management of traffic closures has a significant impact on the overall losses in travel times of drivers and related economic losses. For this reason, it is necessary to provide sufficient space for the planning process of system deployment. At least the following sequence should always be observed: 
- Familiarity with the plan of a closure, traffic routing, the number of lanes and their width, familiarity with traffic volumes at the time of planned closure

- Preparation of a model of traffic closure

- Determining a predicted delay with and without management

- Calculation of CIES

- Decisions about the form of the system, its functions (managing, warning, surveillance, etc.) and the number of components depending on information gained in previous steps

\section{References}

1. Barrel, W., Pesti G., Sun D., Ding L. (2009) Capacity and road user cost analysis of selected freeway work zones in Texas, Texas: Texas Transportation Institute.

2. Calvert, S. (2009) A-Priori Travel Time Predictor for Long Term Roadworks on Motorways. Delft: Delft University of Technology.

3. Akcelik, R. (2008) The Relationship between Capacity and Driver Behaviour. In: TRB National Roundabout Conference, Victoria, May 2008, Kansas City.

4. Highway directoriate of Czech Republic. (2013) Zobrazování zpráv na informačních vozících na dálnicích a rychlostních silnicích ve správě Ředitelství silnic a dálnic ČR - Př́ručka VMS: Ředitelství silnic a dálnic.

5. Highway directoriate of Czech Republic. (2013) Projekt dopravní telematiky při modernizaci dálnice D1: Ředitelství silnic a dálnic

6. Přibyl, P. (2012) Dopravni telematika při modernizaci D1 - conceptual project, Praha: České vysoké učení technické v Praze, fakulta dopravní.

7. Higway directoriate of Czech Republic. (2012) Prováděci pokyny pro hodnoceni ekonomické efektivnosti projektů silničních a dálničnich staveb - Technické předpisy, Ředitelství silnic a dálnic.

8. Fedorčák, D., Kocyan, L., Hájek, M., Szturcová, D., Martinovič, J. (2014) viaRODOS: Monitoring and Visualisation of Current Traffic Situation on Highways. In: Computer Information Systems and Industrial Management, Lecture Notes in Computer Science Volume 8838, pp 290-300 